\title{
SUCROSE IN DETOXIFICATION OF COFFEE PLANTS WITH GLYPHOSATE DRIFT
}

\author{
Ademilson de Oliveira Alecrim ${ }^{1}$, Rubens José Guimarães², Dalyse Toledo Castanheira ${ }^{3}$, \\ Tiago Teruel Rezende ${ }^{4}$, Milene Alves de Figueiredo Carvalho ${ }^{5}$, Giovani Belutti Voltolini ${ }^{6}$
}

(Received: October 01, 2018; accepted: March 01, 2019)

\begin{abstract}
The weed control in coffee plants has great importance, as they compete for light, water and nutrients. The chemical control is the most used, emphasizing the glyphosate, however, when applied, drift can occur and consequently cause injuries to coffee. Many farmers use the sucrose application with the objective to reverse the damage caused by the herbicide drift, even without scientific basis to justify such action. The objective of this study was to evaluate the effect of the sucrose application on the detoxification of coffee plants in the implantation phase with glyphosate drift. The experiment was carried out in a greenhouse, using a randomized block design, arranged in a $3 \times 3$ factorial scheme with 2 additional treatments, using 3 sucrose doses (2, 4 and 8\%) with 3 application times (1, 24 and 168 hours after intoxication with $10 \%$ of the commercial glyphosate dose) with an additional one in which the plants were not intoxicated and not treated with sucrose and another only with plants intoxicated by glyphosate. After 75 days performing the experiment, growth, physiological and anatomical characteristics were evaluated. The application of sucrose in the reversal of intoxication of growth variables (height, leaf area number of leaves, shoot dry weight and dry weight of the root system) was not efficient. The objective of this study was to evaluate the effect of the sucrose application on the detoxification of coffee plants in the implantation phase with glyphosate drift. For the physiological variables the application of $2 \%$ sucrose, one hour after glyphosate intoxication was the most efficient treatment.
\end{abstract}

Index terms: Coffea arabica, anatomy; physiology, intoxication, herbicide.

\section{SACAROSE NA DESINTOXICAÇÃO DE PLANTAS DE CAFEEIRO COM DERIVA DE GLYPHOSATE}

RESUMO: O manejo de plantas daninhas em cafeeiros é de grande importância, pois elas competem por luz, água e nutrientes. O controle químico é o mais utilizado, destacando-se o uso do glyphosate, porém, quando aplicado, pode ocorrer deriva e consequentemente provocar injúrias ao cafeeiro. Muitos cafeicultores utilizam a aplicação de sacarose com o objetivo de reverter os danos causados pela deriva do herbicida, mesmo sem embasamento científico que justifique tal ação. Objetivou-se avaliar o efeito da aplicação de sacarose na desintoxicação de cafeeiros em fase de implantação com deriva de glyphosate. $\mathrm{O}$ experimento foi conduzido em casa de vegetação, utilizando-se o delineamento em blocos casualizados, disposto em esquema fatorial 3 x 3 com 2 tratamentos adicionais, em que utilizaram-se 3 doses de sacarose (2, 4 e 8\%) com 3 tempos de aplicação (1, 24 e 168 horas após a intoxicação com 10\% da dose comercial de glyphosate) com um adicional em que as plantas não foram intoxicadas e não tratadas com sacarose e o outro adicional apenas com plantas intoxicadas por glyphosate. Após 75 dias de condução, avaliaram-se características de crescimento, fisiológicas e anatômicas. A aplicação de sacarose na reversão da intoxicação de variáveis de crescimento (altura, área foliar, Número de folhas, peso seco da parte aérea e peso seco do sistema radicular) não apresentou eficiência. Para as variáveis fisiológicas a aplicação de $2 \%$ de sacarose, uma hora após a intoxicação com glyphosate foi o tratamento mais eficiente.

Termos para indexação: Coffea arabica, anatomia, fisiologia, intoxicação, herbicida.

\section{INTRODUCTION}

Coffee cultivation has great importance to Brazil, which is the world's largest producer and exporter of coffee (CONAB, 2018).

The weeds' management in coffee crop is a very important practice, as these can compete for light, water and nutrients and negatively affect vegetative growth (RONCHI; SILVA, 2006).

The first year after planting of the seedlings in the field is characterized as the most critical phase of weed control in the coffee crop (SILVA et al., 2008), for even young plants leave large areas of soil exposed to light, favoring the growth of weeds. In addition, young coffee plants present slower growth when compared to weeds (SILVA; RONCHI, 2008), favoring competition, being the control of fundamental importance for the good development of the crop.

Among the various weed control methods used in the coffee plant, chemical control with the use of herbicides stands out. This method is one of the most efficient and, in many cases, more economical (YAMASHITA et al., 2008), besides the application practicality, quickness of action and not soil revolving.

1,2,3,6Universidade Federal de Lavras/UFLA - Departamento de Agricultura/DAG - Cx. P. 3037 - 37.200-000 - Lavras - MG ademilsonagronomia@gmail.com, rubensjoseguimaraes@gmail.com,dalysecastanheira@hotmail.com, iovanibelutti77@hotmail.com ${ }^{4}$ Universidade José do Rosário Vellano/UNIFENAS - Rodovia MG 179, Km 0 - 37.132-440- tiagoter@gmail.com

${ }^{5}$ Embrapa Café - Parque Estação Biológica - Av. W3 Norte - Cx. P. 40.315 - 70.770-900 - Brasília - DF - milene.carvalho@embrapa.br 
Among the herbicides used to control weeds in coffee plants, glyphosate stands out, which has a systemic action, post-emergence and does not have coffee selectivity (AMARANTE JUNIOR; SANTOS, 2002). However, the glyphosate use, without observing the technology principles of agrochemicals application can cause "drift" and consequently injuries to the coffee. In order to avoid such injuries some coffee growers adopt some management techniques to avoid (directed jet, special nozzles, etc.) or to reverse (use of sugar spraying) the drift effect which, in the case of sugar application, does not scientific basis. The sugar application without scientific basis (doses, forms and times of application) increase the cost of production, and no guarantee of problem resolution.

Carbon is fundamental in the photosynthesis process, more active this process, less prone to intoxication will be the plants, or the sooner they will recover if intoxication has already occurred (TAIZ; ZEIGER, 2013).

Leaf spraying with dilute sugar solution (sucrose), as a source of carbon for plants, makes it possible to acquire carbon from plants through the photosynthetic pathway (SILVA et al., 2003). As this process is easily affected by adverse edaphoclimatic conditions, many technicians and coffee growers believe that the exogenous supply of carbon, via sucrose application, molasses or amino acids, can efficiently supply this element to the plant (Silva et al., 2003).

The work with sucrose application was done in other crops such as the study of the sucrose application role in the tolerance of Arabidopsis thaliana seedlings to the herbicide atrazine, in which Ramel et al. (2007) found that sucrose can induce tolerance to various xenobiotics types. In coffee, to date, no conclusive studies have been found indicating induction of tolerance to glyphosate drift, or even greater recovery of the plants with the use of sucrose.

The objective in this study was to evaluate the effect of the sucrose application on the detoxification of coffee plants in the implantation phase with glyphosate drift.

\section{MATERIAL AND METHODS}

The experiment was carried out in 2015, in a greenhouse, in the municipality of LavrasMG. Coffea arabica plants of the cultivar Catuaí IAC 99 were used. At the six pairs of leaves stage, completely expanded, it was realized the transplanting of coffee seedlings into pots containing 11 Liters of sieved and previously corrected soil was carried out in order to raise the base saturation to $60 \%$ (RIBEIRO et al., 1999). The soil used in the experiment was classified as a clayey, dystrophic dark red Latosol (EMBRAPA, 2006).

Fertilization planting and coverage were carried out according to the recommendations by Ribeiro et al. (1999). During conducting the experiment weed control was performed manually and the soil was maintained at field capacity.

The experiment consisted of 11 treatments arranged in a $3 \times 3+2$ factorial scheme, in a randomized block design, with four replicates. The treatments were consisted of the combinations between the sucrose levels $(2,4$ and $8 \%$, equivalent to 20,40 and $80 \mathrm{~g} \mathrm{~L}^{-1}$ ) and sucrose application time (1, 24 and 168 hours after a simulation of the glyphosate drift) and more two additional treatments, in which one was applied pure water (standard) and in the other was made the simulation of the glyphosate drift (intoxicated seedlings). Each plot consisted of one plant.

At 56 days after transplanting seedlings, the glyphosate drift was simulated using the original Roundup ${ }^{\circledR}$ commercial formulation, using a costal pressurized sprayer $\mathrm{CO}_{2}$, calibrated at a constant pressure of $250 \mathrm{kPa}$, fitted with a bar and a fan-type nozzles (TT 11002), which allowed the application $200 \mathrm{~L} \mathrm{ha}^{-1}$ of syrup on the plants. To simulate drift, it was used $10 \%(144 \mathrm{ml})$ of the recommended glyphosate dose $1440 \mathrm{ml} \mathrm{ha}^{-1}$.

For the sucrose application, the same sprayer was used in the glyphosate application, but adjusted to apply a syrup volume $400 \mathrm{~L} \mathrm{ha}^{-1}$.

All the evaluations were carried out 75 days after the treatments application and checking plant height $(\mathrm{cm})$; number of leaves and leaf area $\left(\mathrm{cm}^{2}\right)$ (CUNHA et al., 2010). Physiological evaluations were also carried out using a Portable Photosynthesis System (IRGA LICOR - 6400/ $\mathrm{XT})$, quantifying the photosynthetic rate $(\mu \mathrm{mol}$ $\mathrm{CO}_{2} \mathrm{~m}^{-2} \mathrm{~s}^{-1}$ ), a stomatal conductance $\left(\mathrm{mol} \mathrm{H}_{2} \mathrm{O}\right.$ $\left.\mathrm{m}^{-2} \mathrm{~s}^{1}\right)$ and the transpiration rate $\left(\mathrm{mmol} \mathrm{H}_{2} \mathrm{O} \mathrm{m}^{2}\right.$ $\mathrm{s}^{-1}$ ). For these evaluations, completely expanded leaves of plagiotropic branches of the middle third of the plants, located at the third node, were used from the branch apex.

For the anatomical studies, a completely expanded leaf was collected from the third node of plagiotropic branches, from the middle third of the plants. The leaves collected from each plant 
were placed in a container containing $70 \%$ ethanol solution $\left(\mathrm{v} \mathrm{v}^{-1}\right)$ to fix the plant material. After 72 hours the solution was renewed for preservation of the material. In the laboratory, two blades were assembled for each collected leaf, one blade with cross sections and another blade with paradermal sections.

The cross sections were obtained in a LPC-type tabletop microtome and the free-hand paradermal sections using a steel blade followed by the methodology proposed by Kraus; Arduin (1997) until the final preparation of the blade.

The blades were observed and photographed under an Olympus BX 60 model optical microscope coupled to the Canon A630 digital camera. The images were analyzed in UTHSCSAImagetool image analysis software. The diameter $(\mu \mathrm{m})$ of the phloem was evaluated.

At the end of the experiment the plants were sectioned in the colon region, separating them in aerial part and root. Then, these were washed in running water and after in distilled water and placed in paper bags to be dried in an oven with forced air circulation at $65{ }^{\circ} \mathrm{C}$ until constant weight. After drying, each sample was weighed on a precision balance, determining the shoot dry weight and the root system (g).

For the statistical analysis, linear models were fitted to the data. After adjustment, the variance analysis was carried out, in which the effects of sucrose factors, application time and interaction were tested by the $\mathrm{F}$ test. The comparisons among the additional treatments with the treatments of the factorial part were made by means of orthogonal contrasts, which were also tested by the F test.

For the models and the contrasts adjustment, the function aov () of the stats library was used. The variance analysis was performed by the function aov (), also present in the stats library. In the response variables in which some of the factors had a significant effect ( $p$-value> 0.05 ), the average study was done by comparing the confidence intervals at the $95 \%$ level for the adjusted averages by means of the lsmeans function ( ) of the lsmeans library (LENTH; WEISBERG, 2016).

All the procedures to carry out analyzes were done by software R version 3.2.3 (R CORE TEAM, 2016).

\section{RESULTS AND DISCUSSION}

Plants that were intoxicated with glyphosate did not show visible and pronounced symptoms of intoxication 75 days after glyphosate application. There was an interaction effect (Time x Sucrose) for the variables stem diameter, photosynthetic rate, stomatal conductance and transpiration rate, in function of time and sucrose dose (\%) applied.

For plant height, number of leaves, leaf area, dry shoot mass, dry root mass and phloem thickness were significant effect $(\mathrm{p}>0.05)$ only for sucrose factor. However, for the variables number of plagiotropic branches, stomatal density, abaxial and adaxial epidermal thickness, mesophyll, number of xylem vessels, root system volume and root surface area, there was no significant effect ( $p$ $<0.05$ ) of the time and sucrose factors.

Coffee plants that were not intoxicated and received only water (pattern) were superior in height, number of leaves, leaf area and shoot dry mass compared to coffee plants that were intoxicated with no sucrose treatment (intoxicated) (Tables 1 and 2).

This result evidences the negative effects caused by glyphosate intoxication in coffee plants (FRANÇA et al., 2010a; FRANÇA et al., 2010b; FRANÇA et al., 2013).

Also in relation to the variables mentioned above, coffee plants with standard treatment were superior to the intoxicated coffee plants that received the application of sucrose at the dose $2 \%$. It was also observed that coffee plants intoxicated and with no sucrose treatment did not present differences of the intoxicated coffee plants that received sucrose spraying, regardless of the applied dose. On the other hand, the supply of 4 and $8 \%$ of sucrose in coffee plants intoxicated with glyphosate resulted in an equivalent growth of plants that were not intoxicated in height, number of leaves and leaf area (Table 1).

Thirty-five percent of the dry matters of the plants on the planet are represented by derivatives of the shikimate pathway (FRANZ, MAO; SIKORSKI, 1997). As glyphosate-intoxicated plants have the shikimate pathway interrupted by the action of glyphosate (VELINE et al., 2008), it is explained the lower value of dry mass of coffee plants under glyphosate effect observed in the present study.

For the dry mass of the root system (Table 2 ), it was observed that there was no difference among the coffee plants from the standard treatment and the coffee plants intoxicated and not treated with sucrose, demonstrating that the intoxication with glyphosate at $10 \%$ dose did not cause negative effects to the coffee root system. 
TABLE 1 - Height ( $\mathrm{cm})$, number of leaves, leaf area $\left(\mathrm{cm}^{2}\right)$ of coffee plants intoxicated with glyphosate in function of sucrose dose (\%) applied

\begin{tabular}{cccc}
\hline Treatments & Height & Number of leaves & Leaf area \\
\hline 2 & $44.90(43.30-46.50) \mathrm{b}$ & $40.67(35.51-45.82) \mathrm{b}$ & $465.80(393.00-538.60) \mathrm{b}$ \\
4 & $45.40(43.8-47.0) \mathrm{ab}$ & $46.17(41.01-51.32 \mathrm{ab}$ & $547.90(475.10-620.80) \mathrm{ab}$ \\
8 & $46.51(44.91-48.11) \mathrm{ab}$ & $47.67(42.51-52.82) \mathrm{ab}$ & $543.70(470.00-616.60) \mathrm{ab}$ \\
Intoxicated & $44.30(41.53-47.07) \mathrm{b}$ & $36.75(27.83-45.67) \mathrm{b}$ & $411.70(285.50-537.80) \mathrm{b}$ \\
Pattern & $49.60(46.83-52.37) \mathrm{a}$ & $56.50(47.58-65.42) \mathrm{a}$ & $745.80(619.60-872.00) \mathrm{a}$ \\
\hline VC $(\%)$ & 5.88 & 17.59 & 23.38
\end{tabular}

*For each variable, average followed by the same lowercase letter, and by the same capital letter in the line, do not differ from each other by the overlapping confidence intervals system $(\mathrm{p}<0.05)$.

TABLE 2 - Shoot dry weight (g) and root system dry weight (g) of coffee plants intoxicated with glyphosate in function of sucrose dose (\%) applied.

\begin{tabular}{ccc}
\hline Treatments & Shoot dry weight & Root system dry weight \\
\hline 2 & $17.4(15.7-19.09) \mathrm{b}$ & $6.28(5.42-7.14) \mathrm{b}$ \\
4 & $19.12(17.43-20.82) \mathrm{b}$ & $5.83(4.97-6.69) \mathrm{b}$ \\
8 & $18.85(17.15-20.54) \mathrm{b}$ & $6.46(5.60-7.32) \mathrm{ab}$ \\
Intoxicated & $16.18(13.24-19.11) \mathrm{b}$ & $6.98(5.49-8.48) \mathrm{ab}$ \\
Pattern & $25.28(22.43-28.21) \mathrm{a}$ & $8.71(7.21-10.2) \mathrm{a}$
\end{tabular}

$\mathrm{VC}(\%)$

14.88

21.81

*For each variable, average followed by the same lowercase letter, and by the same capital letter in the line, do not differ from each other by the overlapping confidence intervals system $(p<0.05)$.

Also Velini et al. (2008) observed no negative effects on the corn root system, conventional soybeans, Eucalyptos grandis, Commelina benghalensis and Pinus caribaea, when glyphosate was applied, possibly because of the slower effects on this part of the plants. Wagner Júnior et al. (2008) also reported that doses up to $345.6 \mathrm{~g} \mathrm{ha}^{-1}$ of glyphosate applied on yellow passion fruit did not promote root length reduction at 28 days after application.

Intoxicated coffee plants that received $2 \%$ sucrose one hour after glyphosate intoxication had higher photosynthetic rates and stomatal conductance when compared to coffee plants that were intoxicated with no sucrose treatment (Tables 3, 4 and 5).

Also, Martin (2003) concluded that the coffee plants spraying with $2 \%$ sugar, a week after glyphosate drift was efficient in the reversion process of intoxication by this herbicide. In the present work the higher photosynthetic efficiency observed in plants treated with $2 \%$ sucrose after one hour of glyphosate intoxication may have been caused by adaptive defense mechanisms.
It is known that stress caused by xenobiotics, such as glyphosate, causes oxidative stress in plants (RAMEL et al., 2009a). The sucrose application in plants of Arabidopsis thaliana intoxicated with atrazine was efficient to trigger defense mechanisms, activating antioxidant systems and altering the levels of reactive oxygen species (RAMEL et al., 2009a, b).

For the phloem thickness (Table 6) there was no sucrose effect, and the standard coffee plants showed no difference in relation to the intoxicated coffee plants and without sucrose. The leaves phloem thickness of intoxicated coffee plants that received application with $2 \%$ and $4 \%$ of sucrose was higher than those that received $8 \%$.

These results confirm the anatomical modification for this characteristic among the plants intoxicated and treated with different sucrose dosages. It is through the phloem vessels that photo-assimilates translocation occurs, such as sucrose, produced during the photosynthetic process (GRIFFITHS et al., 2016). 
TABLE 3 - Photosynthetic rate $\left(\mu \mathrm{mol} \mathrm{CO} \mathrm{Cm}^{-2} \mathrm{~s}^{-1}\right)$ of coffee plants intoxicated with glyphosate in function of time and sucrose dose (\%) applied.

\begin{tabular}{cccc}
\hline & \multicolumn{3}{c}{ Application time (hours) } \\
\cline { 2 - 4 } Treatments & 1 & 24 & 168 \\
\hline 2 & $7.34(6.01-8.68) \mathrm{aA}$ & $4.96(3.63-6.30) \mathrm{aAB}$ & $4.26(2.93-5.6) \mathrm{aB}$ \\
4 & $5.94(4.61-7.28) \mathrm{abA}$ & $4.94(3.29-5.96) \mathrm{aA}$ & $4.63(3.60-6.27) \mathrm{aA}$ \\
8 & $4.24(2.91-5.58) \mathrm{abA}$ & $6.28(4.94-7.61) \mathrm{aA}$ & $4.98(3.65-6.32) \mathrm{aA}$ \\
Intoxicated & $4.41(3.08-5.75) \mathrm{b}$ & $4.41(3.08-5.75) \mathrm{a}$ & $4.41(3.08-5.75) \mathrm{a}$ \\
Pattern & $4.73(3.40-6.07) \mathrm{ab}$ & $4.73(3.40-6.07) \mathrm{a}$ & $4.73(3.40-6.07) \mathrm{a}$ \\
\hline VC $(\%)$ & & 25.23 &
\end{tabular}

*For each variable, average followed by the same lowercase letter, and by the same capital letter in the line, do not differ from each other by the overlapping confidence intervals system $(\mathrm{p}<0.05)$.

TABLE 4 - Stomatal conductance $\left(\mathrm{mol} \mathrm{H}_{2} \mathrm{O} \mathrm{m}^{-2} \mathrm{~s}^{1}\right)$ of coffee plants intoxicated with glyphosate in function of time and sucrose dose (\%) applied.

\begin{tabular}{cccc}
\hline & \multicolumn{3}{c}{ Application time (hours) } \\
\cline { 2 - 4 } Treatments & 1 & 24 & 168 \\
\hline 2 & $0.087(0.067-0.107) \mathrm{aA}$ & $0.045(0.024-0.065) \mathrm{aB}$ & $0.040(0.019-0.060) \mathrm{aB}$ \\
4 & $0.055(0.034-0.075) \mathrm{abA}$ & $0.040(0.019-0.060) \mathrm{aA}$ & $0.052(0.032-0.072) \mathrm{aA}$ \\
8 & $0.040(0.019-0.060) \mathrm{bA}$ & $0.070(0.049-0.090) \mathrm{aA}$ & $0.052(0.032-0.072) \mathrm{aA}$ \\
Intoxicated & $0.037(0.017-0.057) \mathrm{b}$ & $0.037(0.017-0.057) \mathrm{a}$ & $0.037(0.017-0.057) \mathrm{a}$ \\
Pattern & $0.037(0.017-0.057) \mathrm{b}$ & $0.037(0.017-0.057) \mathrm{a}$ & $0.037(0.017-0.057) \mathrm{a}$ \\
\hline $\mathrm{VC}(\%)$ & & 38.1 &
\end{tabular}

*For each variable, average followed by the same lowercase letter, and by the same capital letter in the line, do not differ from each other by the overlapping confidence intervals system $(\mathrm{p}<0.05)$.

TABLE 5 - Transpiratory rate (mmol H2O m-2 s-1) of coffee plants intoxicated with glyphosate in function of time and sucrose dose (\%) applied.

\begin{tabular}{cccc}
\hline & \multicolumn{3}{c}{ Application time (hours) } \\
\cline { 2 - 4 } Treatments & 1 & 24 & 168 \\
\hline 2 & $1.370(1.123-1.617) \mathrm{aA}$ & $0.767(0.502-1.015) \mathrm{abB}$ & $0.902(0.655-1.150) \mathrm{aAB}$ \\
4 & $0.920(0.767-1.157) \mathrm{abA}$ & $0.820(0.572-1.067) \mathrm{abA}$ & $0.925(0.677-1.172) \mathrm{aA}$ \\
8 & $0.897(0.6501-1.145) \mathrm{bA}$ & $1.207(0.9601-1.455) \mathrm{aA}$ & $1.047(0.800-1.295) \mathrm{aA}$ \\
Intoxicated & $0.637(0.390-0.8849) \mathrm{ab}$ & $0.637(0.390-0.8849) \mathrm{b}$ & $0.637(0.390-0.8849) \mathrm{a}$ \\
Pattern & $0.777(0.5003-1.2025) \mathrm{b}$ & $0.777(0.5003-1.2025) \mathrm{ab}$ & $0.777(0.5003-1.2025) \mathrm{a}$ \\
\hline $\mathrm{VC}(\%)$ & & 26.45 & \\
\hline
\end{tabular}

*For each variable, average followed by the same lowercase letter, and by the same capital letter in the line, do not differ from each other by the overlapping confidence intervals system $(\mathrm{p}<0.05)$. 
TABLE 6 - Diameter $(\mu \mathrm{m})$ of phloem vessels of coffee leaves intoxicated with glyphosate in function of sucrose dose (\%) applied.

\begin{tabular}{cc}
\hline Treatments & Diameter $(\mu \mathrm{m})$ of phloem vessels \\
\hline 2 & $39.43(37.93-40.94) \mathrm{a}$ \\
4 & $38.90(37.39-40.40) \mathrm{a}$ \\
8 & $35.37(33.87-36.88) \mathrm{b}$ \\
Intoxicated & $38.11(35.5-40.72) \mathrm{ab}$ \\
Pattern & $36.3(33.69-38.91) \mathrm{ab}$ \\
\hline VC $(\%)$ & 7.37
\end{tabular}

*For each variable, average followed by the same lowercase letter, and by the same capital letter in the line, do not differ from each other by the overlapping confidence intervals system $(\mathrm{p}<0.05)$.

In the present work it is noticed that application of $2 \%$ sucrose in coffee plants intoxicated with glyphosate presented positive results for photosynthetic and transpiration rate and also for leaf phloem thickness. It is important to emphasize that the evaluations were carried out 75 days after treatments application, but the effects can be even more severe, harming the plants growth over time.

\section{CONCLUSIONS}

The application of sucrose in the reversal of intoxication of growth variables (height, leaf area, number of leaves, shoot dry weight and dry weight of the root system) was not efficient.

For the physiological variables the application of $2 \%$ sucrose, one hour after glyphosate intoxication was the most efficient treatment.

\section{ACKNOWLEDGEMENTS}

The authors are grateful to $C N P q, C A P E S$, FAPEMIG and the Consórcio Pesquisa Café for financial support to carry out the work.

\section{REFERENCES}

AMARANTE JUNIOR, $\mathrm{O}$, $\mathrm{P}$, et al. Glifosato: propriedades, toxicidade, usos e legislação. Química Nova. São Paulo-SP, vol.25, n.4, pp.589-593, 2002.

CASTRO, E. M., PEREIRA, F. J.; PAIVA, R. Histologia vegetal: estrutura e função de órgãos vegetativos. Lavras: Ed. UFLA, 2009.

\section{COMPANHIA NACIONAL DE ABASTECIMENTO}

- CONAB. Acompanhamento da safra brasileira. 2016. Disponível em: <http://www.conab.gov.br>. Acesso em: 02 out. 2018.
CUNHA, J. L. X. L. et al. Comparação de métodos de área foliar em Chrysobalanus icaco L. Agropecuária Científica no Semiárido, Campina Grande, PB, v. 6, p. 22-27, 2010.

EMBRAPA. Sistema brasileiro de classificação de solos. 2. ed. Rio de Janeiro: Embrapa Solos, 2006.

FRANÇA, A. C. et al. Crescimento de cultivares de café arábica submetidos a doses do glyphosate. Planta Daninha, Viçosa, MG, v. 28, p. 599-607, 2010b.

FRANÇA, A. C. et al. Teores de nutrientes em cultivares de café arábica submetidos à deriva de glyphosate. Planta Daninha, Viçosa, MG, v. 24, p. 877-885, 2010 b.

FRANÇA, A.C. et al. Deriva simulada do glyphosate em cultivares de café Acaiá e Catucaí. Planta Daninha, Viçosa, MG, v. 31, p. 443-451, 2013.

FRANZ, J. E., MAO, M. K.; SIKORSKI, J. A. Glyphosate: a unique global herbicide. Washington: American Chemical Society, 1997.

GRIFFITHS, C. A., MATTHEW, P. J.; CHRISTINE, F, $\mathrm{H}$. Metabolite transport and associated sugar signalling systems underpinning source/sink interactions. Biochimica e Biophysica Acta, v. 1857, p. 1715-1725, 2016.

JORGE, L. A. C.; RODRIGUES, A. F. O. (2008). Safira: sistema de análise de fibras e raízes. Boletim de Pesquisa e Desenvolvimento da Embrapa Instrumentação Agropecuária, São Carlos, 24, 21.

RAMEL, F. et al. Natural variation reveals relationships between pre-stress carbohydrate nutritional status and subsequent responses to xenobiotic and oxidative stress in Arabidopsis thaliana. Annals of botany, v. 104, p. 1323-1337, 2009a. 
RAMEL, F. et al. Differential patterns of reactive oxygen species and antioxidative mechanisms during atrazine injury and sucrose-induced tolerance in Arabidopsis thaliana plantlets. BMC Plant Biology, v. 9, p. 1, 2009b

RAMEL, F. et al. Genome-wide interacting effects of sucrose and herbicide-mediated stress in Arabidopsis thaliana: novel insights into atrazine toxicity and sucrose-induced tolerance. BMC genomics, v. 8, p. 1, 2007.

RIBEIRO, A. C., GUIMARÃES, P. T. G.; ALVAREZ VIEGAS, V. H. (Ed.). Recomendações para o uso de corretivos e fertilizantes em Minas Gerais: 5a aproximação. Viçosa, MG: Comissão de Fertilidade do Solo do Estado de Minas Gerais, p. 2532, 1999.

KRAUS, J. E.; ARDUIN, M. Manual básico de métodos em morfologia vegetal. Rio de Janeiro: EDUR, 1997.

LENTH, J.; WEISBERG, S. An r companion to applied regression. 2nd ed. Washington: Sage, 2016.

MARTIN, S. A. (2003). Pulverização do cafeeiro com açúcar: potencial de uso em mudas submetidas à deficiência hídrica e na recuperação de plantas atingidas por glyphosate. 67, Dissertação (Mestrado em Fisiologia Vegetal) -Universidade Federal de Lavras, 2003.

R DEVELOPMENT CORE TEAM. R: a language and environment for statistical computing. Vienna: R Foundation for Statistical Computing, Disponível em: <http://www.R-project.org $>$. Acesso em: 10 Agosto, 2018.
RONCHI, C. P.; SILVA, A. A. Effects of weed species competition on the growth of young coffee plants. Planta Daninha, Viçosa, MG, v. 24, p. 415-423, 2006.

SILVA, A. A.; RONCHI, C. P. Manejo e controle de plantas daninhas em café. In: Vargas, L \& Roman, E. S. (Org.). Manual de manejo e controle de plantas daninhas. Passo Fundo: Embrapa Trigo, p. 417-475, 2008.

SILVA, A. C. et al. Produtividade e potencial hídrico foliar do cafeeiro 'Catuai' em função da época de irrigação. Revista Brasileira de Engenharia Agrícola e Ambiental, Campina Grande PB. v. 12, p. 21-25, 2008.

SILVA, J. C. et al. D. Invertase and sucrose synthase activities in coffee plants sprayed with sucrose solution. Sci. agric. Piracicaba, Braz, Piracicaba, SP, v, 60, p. 239-244, 2003.

TAIZ, L.; ZEIGER, E. Fisiologia vegetal. 5. ed. Porto Alegre: Artmed, 2013. 954 p.

VELINE, E. D. et al. Glyphosate. Botucatu: FEPAF, 2009.

VELINI, E. D. et al. applied at low doses can stimulate plant growth. Pest Management Science, London. v. 64, 489-496, 2008.

WAGNER JÚNIOR, A. et al. Deriva simulada de formulações comerciais de glyphosate sobre maracujazeiro-amarelo. Planta Daninha, Viçosa, MG, v. 26, p. 677-683, 2008.

YAMASHITA, O. M. et al. Efeito de doses reduzidas de oxyfluorfen em cultivares de algodoeiro. Planta Daninha, Viçosa, MG, v.26, p. 917-921, 2008. 